\title{
FAKTOR-FAKTOR YANG MEMPENGARUHI MOTIVASI BELAJAR IPA SISWA SMP BERBASIS PESANTREN
}

\author{
Euis Pipieh Rubiana ${ }^{1}$, Dadi ${ }^{2}$ \\ 1SMP IT Miftahul huda II JI. Mulyasari No. 40, Ciamis Indonesia \\ 2Universitas Galuh, Jl. R. E. Martadinata No.150, Ciamis, Indonesia \\ E-mail: eprubiana@gmail.com, \\ dadee2012@gmail.com
}

\begin{abstract}
The aims of this study to determine the factors that affect the students' motivation to learn nature of science based on Islamic boarding schools in Ciamis West Java. The participans include 47 students of Junior High School based on Islamic boarding schools in grade 8 . The sample sample was taken by proportional random sampling technique.Descriptive exploratory was used as a method in this research. The data was collected through distributing questionnaires that consisting of 18 statement items, and so conducting interviews with students as respondents. Descriptive quantitative used to analyzed of the data. The result of this study showed that the factors affecting the motivation to learn nature science consisted of needs, expectations, aspirations of students, rewards and environmental conditions. Based on these results, it can be concluded that the factors that influence the motivation to learn nature of science in Islamic boarding schools consist of intrinsic and extrinsic factors. The these results, it can be concluded that the factors that influence the motivation to learn nature of science in Islamic boarding schools consist of intrinsic and extrinsic factors.
\end{abstract}

Keyword : extrinsic factors, instrinsic factors, Islamic boarding school, Motivation,

\begin{abstract}
ABSTRAK
Tujuan penelitian untuk mengetahui faktor-faktor yang mempengaruhi motivasi belajar IPA siswa SMP berbasis pesantren. Penelitian ini dilaksanakan di salah satu SMP berbasis pesantren di Kabupaten Ciamis Jawa Barat. Sampel pada penelitian ini adalah siswa kelas VIII yang berjumlah 47 orang dan sampel diambil dengan teknik proportional random sampling. Metode yang digunakan dalam penelitian ini adalah deskriptif eksploratif. Data penelitian diambil melalui penyebaran angket yang terdiri dari 18 item pernyataan, juga dilakukan wawancara kepada siswa sebagai responden. Data dianalisis dengan menggunakan pendekatan deskriptif kuantitatif. Hasil penelitian menunjukkan bahwa faktor-faktor yang mempengaruhi motivasi belajar IPA terdiri dari faktor kebutuhan, harapan, cita-cita siswa , penghargaan dan kondisi lingkungan. Berdasarkan hasil penelitian tersebut, dapat disimpulkan bahwa faktor yang mempengaruhi motivasi belajar IPA di pesantren terdiri dari faktor instrinsik dan faktor ekstrinsik. Implikasi hasil penelitian ini memberikan gambaran perlu dilakukan penelitian lain untuk mengamati faktor-faktor lain yang tidak mempengaruhi motivasi belajar IPA yaitu faktor istrinsik yang mencakup minat dan kemampuan serta faktor ekstrinsik yang mencakup dorongan orang tua dan lingkungan sekolah.
\end{abstract}

Kata kunci: faktor ekstrinsik, faktor intrinsik, motivasi belajar , pesantren

\section{PENDAHULUAN}

Proses pembelajaran yang baik hendaknya merujuk pada peraturan pemerintah nomor 19 tahun 2005 tentang Standar Nasional Pendidikan yang di dalamnya terdapat standar proses. Standar proses yang dimaksud secara garis besarnya dijelaskan Mulyasa (2008:28) diselenggarakan secara interaktif, inspiratif, menyenangkan, menantang, memotivasi peserta didik agar berpartisipasi aktif, serta memberikan ruang yang cukup bagi kreativitas dan kemandirian se-suai dengan bakat dan minat peserta didik. Pendidikan di Indonesia mempunyai beberapa model pendidikan diantaranya yaitu pendidikan sekolah dan pendidikan pesantren (Nurochim,2016:71). Pendidikan sekolah adalah pendidikan yang memberikan pemahaman pada kecerdasan akademik (Suhardi,2012:317). Pendidikan pesantren adalah pendidikan yang erat kaitanya dengan pendidikan agama islam ( Ulum, 2018:21). Saat ini pendidikan menjadi tumpuan bangsa Indonesia untuk melahirkan generasi yang cerdas, dan berkarakter kuat. Baik di pendidikan sekolah atau pendidikan 
pesantren, ada kaarakteristik yang harus dimiliki siswa untuk mencapai keberhasilan belajar. Salah satu karakteristik itu adalah motivasi belajar.

Menurut Slameto (2010:58), proses belajar harus dapat mendorong atau memotivasi siswa agar dapat belajar dengan baik. Motif yang dimiliki siswa adalah pendorong/ penggerak untuk berpikir dan memusatkan perhatian, melaksanakan kegiatan yang menunjang belajar yang dipengaruhi oleh keadaan lingkungan...Motivasi siswa tercermin melalui ketekunan yang tidak mudah patah untuk mencapai sukses meskipun dihadang banyak kesulitan ditunjukkan melalui intensitas untuk bekerja dalam melakukan suatu tugas (Hermawan, 2010:45). Motivasi belajar adalah perilaku belajar yang dilakukan oleh pelajar dan pada dirinya terdapat kekuatan mental yang berupa keinginan, kemauan dan cita-cita (Dimyati dan Mudjiono, 2009:78). Sedangkan menurut Ahmadi dan Prasetya (2005:91), motivasi untuk belajar adalah kondisi psikologis yang mendorong seseorang untuk belajar, hasil penelitian menunjukkan bahwa hasil belajar pada umumnya mening-kat jika motivasi untuk belajar bertambah.

Motivasi belajar dipengaruhi oleh banyak faktor, Purwanto (2011:71) berpendapat bahwa faktor motivasi intrinsik siswa terdiri dari minat, cita-cita dan kondisi siswa, sedangkan faktor motivasi ekstrinsik siswa terdiri dari kecemasan terhadap hukuman, penghargaan dan pujian, peran orang tua, peran pengajar dan kondisi lingkungan. Menurut Majid (2013:311), faktor motivasi dibagi yang terbagi menjadi faktor internal dan faktor eksternal.

1) Faktor internal yaitu faktor yang berasal dari dalam diri individu yang terdiri dari kebutuhan baik kebutuhan fisik maupun psikis, persepsi individu mengenai diri sendiri yang akan mendorong dan mengarahkan perilaku seseorang untuk bertindak, harga diri dan prestasi, danya cita-cita dan harapan masa depan, keinginan untuk maju, minat dan kepuasan ki-nerja.

2) Faktor eksternal yaitu faktor yang berasal dari luar individu terdiri dari pemberian hadiah, kompetisi, hukuman, pujian, imbalan yang di-terima dan situasi lingkungan pada umumnya.

Penelitian yang berkaitan dengan motivasi belajar siswa pada pendidikan sekolah sudah banyak dilakukan. Merujuk pada hasil-hasil penelitian motivasi di pendidikan sekolah, maka penelitian pada pendidikan pesantren pun dilakukan, khususnya pada mata pelajaran IPA. Hakikat pelajaran IPA meliputi produk, proses dan sikap. Temuan di lapangan menunjukkan bahwa motivasi siswa terhadap pelajaran IPA masih rendah, hal ini dapat dibuktikan dengan sikap siswa dalam pembelajaran IPA yang seringkali mengabaikan tugas dari guru. Motivasi siswa dalam pembelajaran IPA dipengaruhi oleh banyak faktor sehingga untuk dapat menciptakan suasana pembelajaran IPA yang menyenangkan dan dapat meningkatakan motivasi siswa. Kondisi di lapangan tersebut mendorong peneliti melakukan penelitian mengenai faktor intrinsik dan faktor ekstrinsik yang mempengaruhi motivasi belajar IPA siswa SMP Islam Terpadu di salah satu SMP di Kabupaten Ciamis Jawa Barat. Hasil penelitian ini diharapkan dapat dijadikan pertimbangan bagi guru untuk memilih metode yang tepat dalam pembelajaran IPA, sehingga dapat meningkatkan motivasi belajar IPA khususnya siswa SMP berbasis pesantren ( SMP terpadu), yang menyelenggarakan sekolah dengan mengintegrasikan dua sistem pendidikan sekolah umum dan pendidikan pesantren yaitu Pondok Pesantren. Meningkatnya motivasi belajar tersebut akan berdampak pada peningkatan hasil belajar. Kedua sistem tersebut merupakan bagian integral dari sistem pendidikan yang diselenggarakan oleh pesantren, sehingga semua peraturan diselenggarakan oleh pesantren. Aktivitas belajar di sekolah sangat dipengaruhi oleh aktivitas yang ada di pesantren, waktu belajar di sekolah dan kelas dipisahkan berdasarkan jenis kelamin, yaitu kelas khusus perempuan merupakan kelas pagi dan kelas khusus laki-laki yang merupakan kelas siang. Hal ini dilakukan untuk mengantisipasi keterbatasan ruangan kelas di sekolah tersebut serta jadwal kegiatan pembelajaran siswa di pondok pesantren. Salah satu Pondok Pesantren di Kabupaten Ciamis ini adalah pesantren Salafiyah yang menyelenggarakan kurikulum terpadu antara bidang studi umum dan bidang studi agama dalam satu sistem yang terpadu secara integral. 
Penelitian ini bertujuan untuk mengetahui faktor-faktor yang mempengaruhi motivasi belajar IPA siswa SMP berbasis pesantren.

\section{METODE}

Metode yang digunakan dalam penelitian ini adalah deskriptif dengan pendekatan kuantitatif. Penelitian ini dilaksanakan di SMP berbasis pesantren (SMP Islam Terpadu), di kelas VIII. Siswa kelas VIII berjumlah 157 orang, siswa yang menjadi sampel dalam penelitian ini berjumlah 47 orang yang terdiri dari 19 siswa perempuan dan 28 siswa laki-laki. Sampel penelitian ini didapat dengan teknik Propotional Random Sampling. Variabel penelitian ini adalah faktor-faktor yang mempe-ngaruhi motivasi belajar IPA yaitu faktorfaktor yang menjadi pendorong siswa untuk belajar IPA baik dari dalam diri siswa (instrinsik) maupun dari luar diri siswa (ekstrinsik). Instrumen penelitian berupa angket tertutup yang terdiri dari 18 item pernyataan dengan skala pengukuran mengacu pada skala Likert. Angket bersifat tertutup dengan lima alternatif jawaban yang telah disediakan. Jawaban dari hasil penyebaran angket diperdalam dengan wawancara terbuka terbatas kepada siswa. Data pada penelitian ini dianalisis dengan menggunakan pendekatan kuantitatif berdasarkan pada total skor jawaban per indikator.

\section{HASIL DAN PEMBAHASAN}

Berdasarkan hasil penelitian yang telah dilakukan terhadap 47 siswa kelas VIII SMP Islam Terpadu diperoleh hasil yang disajikan pada Tabel 1.

Tabel 1. Rekapitulasi per indikator skor motivasi belajar IPA siswa

\begin{tabular}{lllllll}
\hline No Indikator & $\begin{array}{l}\text { Banyak } \\
\text { Soal }\end{array}$ & \multicolumn{2}{l}{ Jumlah Total Skor Siswa } & $\begin{array}{l}\text { Rentang } \\
\text { Ideal }\end{array}$ & Skor & Kategori \\
\hline 1 & 1 & 160 & 47 & - & 235 & Setuju \\
2 & 5 & 779 & 235 & - & 1175 & Ragu-ragu \\
3 & 1 & 179 & 47 & - & 235 & Setuju \\
4 & 2 & 340 & 94 & - & 470 & Setuju \\
5 & 3 & 406 & 141 & - & 705 & Ragu-ragu \\
6 & 2 & 331 & 94 & - & 470 & Setuju \\
7 & 2 & 273 & 94 & - & 470 & Ragu-ragu \\
8 & 1 & 145 & 47 & - & 235 & Ragu-ragu \\
9 & 1 & 175 & 47 & - & 235 & Setuju \\
\hline Total & 18 & 2788 & & & & \\
\hline
\end{tabular}

Keterangan:

*):1 Kebutuhan, 2 Minat, 3 Harapan, 4 Cita-cita, 5 Kemampuan,

6 Penghargaan, 7 Dorongan Keluarga, 8 Kondisi Sekolah 9 Kondisi Lingkungan

Berdasarkan data yang diperoleh dari sebaran jawaban angket dalam rekapitulasi skor per indikator (Tabel 1) dapat dilihat bahwa dari lima indikator intrinsik, hanya tiga indikator yang mempengaruhi motivasi belajar IPA. Sedangkan indikator ekstrinsik yang terdiri dari empat indikator hanya dua indikator yang mempengaruhi motivasi belajar IPA. Dari data tersebut dike-tahui bahwa faktor-faktor yang mem-pengaruhi motivasi belajar IPA siswa SMP berbasis pesantren di SMP Islam Terpadu ini terbagi menjadi indikator intrinsik maupun indikator ekstrinsik. Motivasi belajar siswa yang berasal dari dalam dirinya (intrinsik) adalah kebutuhan, harapan dan cita-cita sedangkan motivasi belajar yang berasal dari luar diri siswa (ekstrinsik) adalah penghargaan dan kondisi ling-kungan.

Indikator intrinsik merupakan faktor motivasi yang berasal dari dalam diri siswa yang mempengaruhi motivasi belajar. Siswa "setuju" bahwa motivasi belajar IPA dipengaruhi oleh adanya kebutuhan terhadap pelajaran IPA sebagai pelajaran yang berman-faat bagi kehidupan sehari-hari. Menurut Purwanto (2011:61) 
tindakan yang dilakukan oleh manusia pada hakikatnya adalah untuk memenuhi kebutuhannya. Hal ini dibuktikan dengan ketekunan dan keuletan siswa dalam mengerjakan setiap tugas IPA dari guru yang juga dipengaruhi oleh harapan siswa dengan menyatakan "setuju" bahwa setiap ketekunan dan keuletan siswa dalam mengerjakan tugas akan mendapat nilai yang terbaik dari guru.

Berdasarkan hasil wawancara, 5 dari 8 siswa memiliki harapan yang tinggi setelah mempelajari IPA, harapan tersebut berupa harapan mendapatkan nilai yang baik setelah siswa belajar dan mengerjakan tugas yang diberikan guru IPA mengingat bahwa waktu untuk mengulang dan mengerjakan tugas IPA di luar sekolah sangat terbatas dengan adanya kegiatan di pesantren tempat siswa tinggal. Harapan siswa tersebut harus diimbangi dengan kemampuan siswa serta usaha yang dilakukan oleh siswa dalam mengerjakan tugas IPA yang diberikan oleh guru dengan baik dan tepat waktuinat setiap siswa terhadap mata pelajaran IPA berbeda-beda, siswa menyatakan "ragu-ragu" bahwa minat siswa terhadap pelajaran IPA mempe-ngaruhi motivasinya dalam belajar. Hal ini bertentangan dengan pendapat yang dikemukakan oleh Majid (2013:312) bahwa minat merupakan alat motivasi yang pokok dalam belajar. Berdasarkan hasil wawancara, 3 dari 8 siswa yang memiliki minat IPA selalu bersungguh-sungguh saat belajar dan mengerjakan tugas yang diberikan oleh guru. Akan tetapi, bagi siswa yang memiliki minat rendah terhadap pelajaran IPA beralasan bahwa pelajaran IPA sulit dimengerti, selain itu kurangnya pemahaman mata pelajaran lain sebagai penunjang mata pelajaran IPA masih rendah. Ketersediaan sarana prasarana seperti laboraturium yang memadai dan cara guru menyampaikan mata pelajaran IPA diharapkan tidak hanya mengajarkan teori mengingat hakikat pelajaran IPA adalah produk, sikap dan keterampilan proses yang harus diajarkan pada siswa sehingga dapat meningkatakan minat siswa pada pelajaran IPA.Siswa yang minatnya tinggi berpendapat bahwa Pelajaran IPA memiliki hubungan dengan cita-cita siswa yang "setuju" bahwa pelajaran IPA dapat menunjang cita-citanya di masa depan sehingga siswa lebih termotivasi untuk belajar IPA. Akan tetapi bagi 2 dari 8 siswa menjawab minat siswa untuk belajar IPA kurang karena pelajaran IPA tidak sepenuhnya menjadi penunjang cita-cita siswa di masa depan. Cita-cita siswa yang menjadi motivasi belajar tidak harus diimbangi dengan kemampuan siswa dalam memahami pelajaran IPA. Siswa yang menyatakan "ragu-ragu" membuktikan bahwa kemampuan siswa dalam mempelajari IPA dan mengerjakan tugas-tugas yang diberikan guru di sekolah masih rendah karena hanya $50 \%$ siswa yang nilainya telah memenuhi standar KKM yaitu 72. Berdasarkan hasil wawancara 5 dari 8 siswa yang nilainya sudah memenuhi standar KKM menyatakan bahwa siswa tersebut memiliki harapan yang tinggi terhadap pelajaran IPA sehingga selalu berusaha memanfaatkan waktu istirahat sebaik mungkin untuk mengulang pelajaran IPA meskipun aktivitas di asrama pondok pesantren tempat mereka tinggal sangat padat. Siswa lain yaitu 3 dari 8 siswa yang nilainya belum memenuhi standar KKM menyatakan bahwa siswa tersebut seringkali mengabaikan tugas guru dengan alasan padatnya aktivitas di pesantren, waktu luang digunakan siswa untuk beristirahat sehingga sama sekali tidak punya waktu mengerjakan tugas sekolah khususnya tugas pelajaran IPA. Salah satu faktor ekstrinsik yang mempengaruhi motivasi belajar adalah lingkungan. Kondisi lingkungan siswa yang bertempat tinggal di asrama dan harus mengikuti semua kegiatan di pesantren menjadi salah satu faktor yang mempengaruhi motivasi belajar IPA siswa dengan menyatakan "setuju". Segala bentuk kegiatan di pesantren yang cukup padat mengharuskan siswa pandai membagi waktu untuk mengulang kembali pelajaran IPA yang telah diberikan guru di sekolah.

Berdasarkan hasil wawancara, 6 dari 8 siswa menyatakan bahwa kondisi lingkungan tempat tinggal siswa yaitu asrama pondok pesantren cukup nyaman, namun padatnya aktivitas belajar di pesantren mengharuskan siswa pandai dalam memanfaatkan waktu luang untuk belajar serta mengerjakan tugas yang diberikan guru di sekolah khususnya pelajaran IPA. Seringkali waktu luang yang dimiliki siswa setelah kegiatan di pesantren selesai digunakan untuk istirahat. Fasilitas pesantren seperti jumlah kamar mandi yang disediakan tidak sebanding dengan jumlah siswa yang ada, selain itu ketersediaan makanan untuk 
sarapan siswa yang tidak tepat waktu menjadi alasan keterlambatan siswa sehingga diharapkan adanya kerjasama dalam pengaturan waktu yang tepat dari pihak sekolah maupun pesantren.

Peran serta orang tua dalam memotivasi siswa sangatlah penting untuk memotivasi siswa. Akan tetapi, siswa tinggal di asrama pondok pesantren dan jauh dari orang tua. Dorongan keluarga tidak didapatkan oleh siswa secara langsung sehingga siswa menjawab "ragu-ragu". Berda-sarkan hasil wawancara, 2 dari 8 siswa memutuskan untuk tinggal dan belajar di pesantren sekaligus sekolah karena perintah dari orang tua, sedangkan 5 dari 8 siswa menjawab belajar di pondok pesantren sekaligus sekolah adalah keinginan sendiri. Tata tertib pondok pesantren hanya memperbolehkan siswa pulang ke rumah dalam waktu tertentu, orang tua siswa juga hanya bisa berkunjung ke pesantren atau sekolah pada waktu tertentu, semua siswa dilarang membawa alat komunikasi seperti telepon genggam sehingga komunikasi yang terjadi antara siswa dan orang tua sangat jarang. Lingkungan siswa yaitu pondok pesantren akan memberikan penghargaan berupa hukuman bagi mereka yang melanggar aturan pesantren. Menurut Majid (2013:313) bahwa penghargaan berupa pujian, pemberian hadiah dan hukuman merupakan alat pendidikan dan pendorong atau motivasi untuk anak. Hukuman ini biasanya disebut dengan ta'jir yaitu melakukan hal yang sifatnya mendidik sebagai imbalan bagi siswa yang melanggar. Siswa "setuju" bahwa penghargaan menjadi salah satu faktor yang mempengaruhi motivasi belajar IPA. Jika pemberian hukuman (ta'jir) ini juga diterapkan di sekolah, diharapkan dapat meningkatkan ke-disiplinan dan motivasi siswa dalam mengikuti setiap pembelajaran di sekolah khu-susnya pada saat pembelajaran IPA. Hukuman yang bisa diterapkan adalah hukuman yang bersifat mendidik dengan efek jera sehingga siswa patuh dan taat terhadap tata tertib sekolah karena adanya hukuman yang diterpakan bagi siswa yang melanggar.

Jika pemberian hukuman (ta'-jir) ini juga diterapkan di sekolah, diharapkan dapat meningkatkan kedisiplinan dan motivasi siswa dalam mengikuti setiap pembelajaran di sekolah khususnya pada saat pembelajaran IPA. Hukuman yang bisa diterapkan adalah hukuman yang bersifat mendidik dengan efek jera sehingga siswa patuh dan taat terhadap tata tertib sekolah karena adanya hukuman yang diterpakan bagi siswa yang melanggar.

Kondisi sekolah tidak begitu berpengaruh terhadap motivasi belajar IPA, siswa menjawab "ragu-ragu" meskipun mereka mengakui bahwa fasilitas sekolah seperti buku-buku sumber mata pelajaran IPA dan tidak lengkapnya laboratorium IPA yang ada di sekolah menjadi kendala saat belajar IPA. Hal ini dapat dipengaruhi oleh beberapa faktor diantaranya item pernyataan yang mungkin kurang sesuai dan sulit dimengerti siswa sehingga tidak sesuai dengan jawaban yang diharapkan. Selain itu, waktu yang digunakan dalam mengisi angket sangat terbatas dan dilakukan pada saat pembelajaran IPA berlangsung. Dengan demikian motivasi yang dipengaruhi oleh beberapa faktor tesebut akan mempengaruhi hasil belajar. Hal ini didukung oleh pendapat Pratiwi (2015) yang menyatakan bahwa hasil belajar dipengaruhi oleh faktor instrinsik dan ekstrinsik, salah satu faktor instrinsik adalah motivasi belajar

\section{SIMPULAN}

Berdasarkan hasil penelitian, maka disimpulkan bahwa faktor-faktor yang mempengaruhi motivasi belajar IPA siswa SMP berbasis pesantren terdiri dari faktor intrinsik dan faktor ekstrinsik. Faktor intrinsik terdiri dari kebutuhan, harapan dan cita-cita, faktor ekstrinsik terdiri dari penghargaan dan kondisi lingkungan. Sedangkan faktor-faktor yang tidak mempengaruhi motivasi belajar IPA antara lain minat dan kemampuan (intrinsik), dorongan keluarga dan kondisi sekolah (ekstrinsik)

\section{DAFTAR PUSTAKA}

Ahmadi, A. dan Prasetya, JT. 2005. Strategi Belajar Mengajar. Bandung: Pustaka Setia. 
Dimyati dan Mudjiono. 2009. Belajar dan Pembelajaran. Jakarta: Rineka Cipta Hermawan, H. 2010. Teori belajar dan Moti-vasi. Bandung: Citra Praya.

Hermawan, H. 2010. Teori belajar dan Motivasi. Bandung: Citra Praya.

Majid, A. 2013. Strategi Pembela-jaran. Bandung: Rosdakarya

Mulyasa. 2008. Kurikulum Tingkat Satuan Pendidikan. Bandung: PT. Remaja Rosdakarya

Nurochim. (2016). "Sekolah Berbasis Pesantren Sebagai Salah Satu Model Pendidikan Islam Dalam Konsepsi Perubahan Sosial" Jurnal Al-Tahrir, 16(1): $69-88$

Pratiwi N. (2015). "Pengaruh Tingkat Pendidikan, Perhatian Orang Tua, dan Minat Belajar Siswa Terhadap Prestasi Belajar Bahasa Indonesia Siswa SMK Kesehatan di Kota Tangerang" Jurnal Pujangga 1 (2):75-105.

Purwanto, N. 2011. Psikologi Pendi-dikan. Bandung: PT. Remaja Rosdakarya.

Slameto. 2010. Belajar dan Faktor-faktor yang Mempengaruhinya. Jakarta: Rineka Cipta.

Suhardi D, (2012). "Peran Smp Berbasis Pesantren Sebagai Upaya Penanaman Pendidikan Karakter Kepada Generasi Bangsa". Jurnal Pendidikan Karakter 2(3):316-328.

Ulum M, (2018). "Eksistensi Pendidikan Pesantren : Kritik Terhadap Kapitalisasi Pendidikan". Jurnal Studi Pendidikan Islam Ta"Lim.1 (2):20-37 